\title{
Analysis of the horizontal corneal diameter, central corneal thickness, and axial length in premature infants
}

\author{
Diâmetro horizontal corneano, espessura corneana central e o comprimento axial em prematuros
}

Ozdemir Ozdemir ${ }^{1}$, Zuhal Özen Tunay ${ }^{1}$, Ikbal Seza Petriçli², Damla Ergintürk Acar ${ }^{1}$, Ugur Acar ${ }^{3}$, Muhammet Kazim Erol ${ }^{4}$

\section{ABSTRACT}

Purpose:To determine the horizontal corneal diameter, central corneal thickness, and axial length in premature infants.

Methods: Infants with a birth weight of less than 2,500 g or with a gestation period of less than 36 weeks were included in the study. Infants with retinopathy of prematurity (ROP) were allocated to Group $1(n=138)$, while those without ROP were allocated to Group $2(n=236)$. All infants underwent a complete ophthalmologic examination, including corneal diameter measurements, pachymetry, biometry, and fundoscopy. Between-group comparisons of horizontal corneal diameter central corneal thickness, and axial lengths were performed. Independent sample $t$-tests were used for statistical analysis.

Results: Data was obtained from 374 eyes of 187 infants (102 female, 85 male) The mean gestational age at birth was $30.7 \pm 2.7$ weeks (range 25-36 weeks), the mean birth weight was 1,514 $\pm 533.3 \mathrm{~g}$ (range 750-1,970 g), and the mean postmenstrual age at examination was $40.0 \pm 4.8$ weeks. The mean gestational age and the mean birth weight of Group 1 were statistically lower than Group $2(p<0.05)$. There were no significant differences in horizontal corneal diameter central corneal thickness, and axial length between the two groups ( $p>0.05$ ).

Conclusions: The presence of ROP in premature infants does not alter the horizontal corneal diameter, central corneal thickness, or axial length.

Keywords: Cornea/anatomy and histology; Retinopathy of prematurity; Infant, premature; Birth weight; Gestational age

\section{RESUMO}

Objetivo: Determinar o diâmetro horizontal corneano, a espessura corneana central e o comprimento axial de prematuros.

Métodos: Crianças com peso de nascimento menor que 2.500 gou idade gestacional menorque 36 semanas foram incluídas no estudo. Recém-nascidos com retinopatia da prematuridade (ROP) foram alocados no Grupo 1 ( $n=138)$, sem ROP foram alocados no Grupo 2 ( $n=236$ ). Todos os bebês foram submetidos a exame oftalmológico completo, incluindo medida do diâmetro corneano, paquimetria, biometria e fundoscopia. O diâmetro horizontal corneano, a espessura corneana central e o comprimento axial dos grupos foram comparados. Teste de "Student" para amostras independentes foi utilizado na análise estatística.

Resultados: Os dados foram obtidos a partir de 374 olhos de 187 crianças (102 meninas, 85 meninos). A idade gestacional média ao nascer foi de 30,7 $\pm 2,7$ semanas (variação de 25 a 36 semanas). O peso médio ao nascer foi de $1.514 \pm 533,3 \mathrm{~g}$ (variação de 750 a 1.970 g). A idade pós-menstrual média de exame foi de 40,0 4 4,8 semanas. A idade gestacional e o peso médio do Grupo 1 eram estatisticamente inferiores aos do Grupo $2(p<0,05)$. Não houve diferenças significativas no diâmetro horizontal da córnea, espessura corneana centrale medidas de comprimento axialentre dois grupos $(p>0,05)$. Conclusões: $A$ presença de ROP em prematuros não altera o diâmetro da córnea horizontal, espessura corneana central e o comprimento axial.

Descritores: Córnea/anatomia \& histologia; Retinopatia da prematuridade; Prematuro; Peso ao nascer; Idade gestacional

\section{INTRODUCTION}

The size of organs in the human body is continually balanced to match their required functional capacity. The eye is one of the most controlled organs in this respect, and its size requires precise adaptation to the optical focal length of the cornea and the lens width ${ }^{(1,2)}$. For full-term newborns, the horizontal corneal diameter is around $9.8 \mathrm{~mm}$ (surface area $102 \mathrm{~mm}^{2}$ ), or approximately $75 \%$ to $80 \%$ the size of the adult human cornea. The posterior segment at birth is also less than $50 \%$ of adult length. During infancy the cornea continues to grow, reaching adult size at two years old, with a horizontal diameter of $11.7 \mathrm{~mm}$ (surface area $138 \mathrm{~mm}^{2}$ ). It changes very little in shape, size, and optical properties thereafter ${ }^{(3)}$.

Ophthalmic ultrasonography is one of the main diagnostic imaging methods used in ocular analysis. Ultrasound comprises acoustic waves of a frequency higher than the upper limit of human hearing
(20 KHz). In medical diagnostics, ultrasound devices detect, process, and amplify echoes of the returning wave. Changes in tissue density result in alterations to the echoes reflecting back to the transducer, where they are converted back into an electrical signal and processed. Thus, the use of ultrasound in medicine depends on the physical laws of acoustic energy, reflection, refraction, and absorption. In ophthalmology, the biometric A-scan is primarily used to determine axial eye lengths. It uses a probe with an operating frequency of 10 to $12 \mathrm{MHz}$ and a linear amplification curve ${ }^{(4)}$.

Retinopathy of prematurity (ROP) is a vasoproliferative retinopathy of infants who are born prematurely and with a low birth weight ${ }^{(5-7)}$. Moreover, ROP can be a potentially blinding condition ${ }^{(8)}$. Some studies have documented alterations in ocular growth and changes in refractive errors in infants with $\mathrm{ROP}^{(9)}$. It is widely recognized that $\mathrm{ROP}$ is a multi-factorial condition, with gestational age, low birth weight,
Funding: No specific financial support was available for this study.

Disclosure of potential conflicts of interest: None of the authors have any potential conflicts of interest to disclose.

Corresponding author: Ozdemir Ozdemir. Göz Hastalıkları Polikliniği. Zekai Tahir Burak Kadın Sağlığı Eğitim ve Araştırma Hastanesi - Talatpaşa Bulvarı. Altındağ, Ankara, Turkey E-mail: ozdemirozdemir@yahoo.com

Project number: Karar № 20-17/01/2013. 
blood transfusion, oxygen exposure, intraventricular haemorrhage, and necrotizing enterocolitis all implicated in the disorder ${ }^{(10,11)}$.

The aim of the present study was to determine the horizontal corneal diameter, central corneal thickness, and axial length in premature infants.

\section{METHODS}

Participitants were recruited from the Zekai Tahir Burak Women's Health Education and Research Hospital. Infants with a birth weight of less than 2,500 g, or with a gestation period of less than 36 weeks, were included in the study. Infants with congenital glaucoma, and anterior or posterior abnormalities such as congenital cataracts, were excluded from the study. Infants treated with laser photocoagulation and/or intravitreal injections also were excluded. The study was approved by the local ethics committee and was performed in accordance with the ethical standards laid down in the Declaration of Helsinki. Parents or guardians of all children gave their informed consent prior to their inclusion in the study.

A single examination was performed on each infant. We recorded the gestational age, birth weight, and postmenstrual age. All infants also underwent a complete ophthalmologic examination, including measurements of corneal diameter, central corneal thickness, axial length, and intraocular pressure. Examinations of the anterior segment and a funduscopy were also performed. For the funduscopic examinations, mydriasis was obtained by the instillation of topical phenylephrine hydrochloride (2.5\%) and topical tropicamide (0.5\%) a minimum of 30 min before examination. After instillation of a topical anaesthetic (0.5\% proparacaine hydrochloride) the eyelids were retracted using a paediatric speculum. For the ROP group, all measurements were recorded following the funduscopy.

Corneal diameters were determined with callipers by measuring the white-to-white limbus horizontally between the 3 and 9 o'clock positions. Biometry and pachymetry measurements were performed with an ultrasound biometer (Compact Touch Ultrasound system, Cedex, France). For biometry A-scan testing, the probe was applied lightly on the centre of the cornea, perpendicular to its axis. Particular attention was paid to avoid corneal indentation. For each eye, the average value of 10 measurements was recorded. Axial length, anterior chamber depth, lens thickness, and vitreous length were all measured by this process. For pachymetry, the probe was placed perpendicularl to the central cornea and an average of 10 consecutive measurements was recorded for each eye.

Between-group comparisons were made for the horizontal corneal diameter, central corneal thickness, axial length, anterior chamber depth, lens thickness, and the vitreous length. ROP infants comprised Group 1 and non-ROP infants comprised Group 2.

\section{Statistical analysis}

Statistical analysis was performed using the computer package program Statistical Package for the Social Sciences ${ }^{\text {TM }} 16.0$ (SPSS Inc. Chicago, IL). Results were reported as the mean \pm standard deviation (SD), frequency, and percentage. Differences between the groups were tested for significance by the independent samples $t$-test. Differences were considered significant at $p<0.05$.

\section{RESULTS}

The data from 374 eyes of 187 (102 female, 85 male) infants were analyzed. The mean gestational age at birth was $30.7 \pm 2.7$ weeks (range 25-36 weeks). The mean birth weight was 1,514 $\pm 533.3 \mathrm{~g}$ (range 750-1,970 g). The mean postmenstrual age at examination was $40.0 \pm$ 4.8 weeks. The mean gestational age and the mean birth weight of Group 1 were statistically lower than Group $2(p<0.05)$. Table 1 shows the characteristics of infants in both groups.
In Group 1, 14 infants (10.1\%) had zone 2 stage 1 ROP, two infants (1.4\%) had zone 2 stage 2 ROP, 102 infants (73.9\%) had zone 3 stage 1 ROP, 20 infants (14.4\%) had zone 3 stage 2 ROP, and four infants (2.8\%) had zone 3 stage 3 ROP.

The horizontal corneal diameter measurements, and the pachymetric and biometric data are presented in table 2. The mean horizontal corneal diameter was $10.1 \pm 0.5 \mathrm{~mm}$. The mean central corneal thickness was $559 \pm 41.8$ microns. The mean anterior chamber depth was $2.1 \pm 0.4 \mathrm{~mm}$. The mean lens thickness was $4.1 \pm 0.6 \mathrm{~mm}$. The mean vitreous length was $10.3 \pm 1.7 \mathrm{~mm}$. The mean axial length was $16.7 \pm 1.0 \mathrm{~mm}$. There was no significant difference in the horizontal corneal diameter, central corneal thickness, or axial length measurements between the two groups ( $p>0.05$ ).

\section{DISCUSSION}

In this study, infants aged between 25 and 36 gestation weeks, and between 750 and 2,500 g birth weight, were examined. ROP screening was performed according to the baby's week of birth and birth weight.

The normal measures of corneal diameter, corneal thickness, and axial length are better known for full-term healthy infants than for premature ones. The mean horizontal diameter of the cornea at birth is reported $10-0 \mathrm{~mm}$, and this increases with advancing gestational age and birth weight ${ }^{(12,13)}$. The mechanism that determines central corneal thickness is not yet fully understood. Fundus examinations reveal that the corneas of premature infants (less than 30 gestational weeks) are often blurred, while most infants of over 31 gestational weeks have sufficient corneal clarity. These findings suggest that corneal hydration in premature infants can play an important role in determining the central corneal thickness ${ }^{(13)}$. Recent studies have shown that corneal thickness in premature babies decreases towards the time of full-term ${ }^{(13,14)}$. Kirwan et al. found that babies born at 31 weeks have thick corneas and that a progressive and statistically significant decrease in thickness occurs towards full-term. Conversely, the horizontal corneal diameter showed a progressive and significant increase in thickness towards full-term. Thus, it was demonstrated that premature infants possess thick corneas with small corneal diameters ${ }^{(15)}$.

Table 1. Characteristics of premature infants with (Group 1) and without (Group 2) ROP

\begin{tabular}{lccc}
\hline & Group 1 & Group 2 & Total \\
\hline Number of eyes & 138 & 236 & 374 \\
Sex & $78 \mathrm{~F}, 60 \mathrm{M}$ & $124 \mathrm{~F}, 112 \mathrm{M}$ & $202 \mathrm{~F}, 172 \mathrm{M}$ \\
Mean gestational age & $29.2 \pm 2.2$ & $31.6 \pm 2.5$ & $30.7 \pm 2.7$ \\
Mean postmenstrual age & $39.4 \pm 4.4$ & $40.6 \pm 5.1$ & $40.0 \pm 4.8$ \\
Mean birth weight & $1201.2 \pm 298.3$ & $1701.8 \pm 547.3$ & $1514.9 \pm 533.3$ \\
\hline
\end{tabular}

$\mathrm{F}=$ female; $\mathrm{M}=$ male.

Table 2. Comparison of the horizontal corneal diameter measurement, pachymetric and biometric data of premature infants with (Group 1) and without retinopathy of prematurity (Group 2)

\begin{tabular}{lrrc}
\hline & Group 1 & Group 2 & p value \\
\hline Mean horizontal corneal diameter (mm) & $10.2 \pm 0.5$ & $10.0 \pm 0.4$ & 0.58 \\
Mean central corneal thickness (microns) & $557.3 \pm 42.7$ & $561.1 \pm 42.1$ & 0.52 \\
Mean anterior chamber depth (mm) & $2.1 \pm 0.4$ & $2.1 \pm 0.3$ & 0.94 \\
Mean lens thickness (mm) & $4.1 \pm 0.7$ & $4.0 \pm 0.5$ & 0.20 \\
Mean vitreous length (mm) & $10.3 \pm 1.5$ & $10.3 \pm 1.9$ & 0.89 \\
Mean axial length $(\mathrm{mm})$ & $16.4 \pm 1.3$ & $16.7 \pm 0.6$ & 0.06 \\
\hline
\end{tabular}


It has also been reported that the eyes of premature infants have shallower anterior chambers, shorter axial lengths, and more highly curved corneas than full-term infants' eyes. In severe cases of ROP these differences become more significant ${ }^{(9)}$. Furthermore, children with larger head sizes or lengths at birth, or who are born heavier or more mature, have deeper vitreous chambers and longer axial lengths ${ }^{(16)}$. Laws et al. studied the ultrasound axial length measurements of infants born with either a birth weight of less than 1,500 g or a gestation period of less than 32 weeks, who had undergone screening for ROP. They reported that, during the period of the study, the mean axial length increased from $15.27 \mathrm{~mm}$ to $16.65 \mathrm{~mm}$ in the left eye, at a growth rate of $0.18 \mathrm{~mm} /$ week. They reported that the axial lengths of the infants was inversely related to increasing stages of ROP, and that infants with the maximum ROP stage had the shortest axial length ${ }^{(17)}$. Similarly, Hirano et al. followed axial length growth in premature and term infants during a one year period, and reported that premature infants had shorter axial length measurements ${ }^{(18)}$.

In contrast to previously published studies, this study did not detect differences in the measurements of corneal diameter, central corneal thickness, or axial length, between infants with or without ROP. We encounter a smaller prevalence of cicatricial ROP in our group. This may be related to attentive screening for ROP, prompt treatment, and advances in the prevention of cicatricial ROP. Therefore, we suggest that severe cases of ROP or cicatricial ROP have become less common. Furthermore, eyes treated with photocoagulation or intravitreal injections for ROP were not included in our analysis and this may influence the results.

The limitations of this study include the small sample size, the short follow-up period, and possibly errors relating to the manual measurements of corneal diameter, central corneal thickness, and axial length. The stages of ROP in this study ranged from stage 1 to stage 3. No stage 4 or 5 examples (cicatricial ROP) were used. Being a single-centre study with pachymetry and ultrasound exams performed by the same clinician may also be considered limitations.

In conclusion, birth weight and gestational age both have an indisputable effect on ocular growth. However, we did not detect an effect of ROP on the horizontal corneal diameter, central corneal thickness, or axial length. We propose that further investigations using the data from more samples are needed in order to obtain more reliable results.

\section{REFERENCES}

1. Wallman J, Winawer J. Homeostasis of eye growth and the question of myopia. Neuron. 2004:43(4):447-68.

2. Schaeffel $F$, Howland HC. Development of ocular refraction: Lessons from animal experiments. In: Lorenz B, Moore AT, editors. Essentials in ophthalmology: Pediatric ophthalmology, neuro-ophthalmology genetics. Berlin: Springer-Verlag; 2006. p.1-18.

3. Dawson DG, Watsky MA, Geroski DH, Edelhauser HF. Cornea and sclera. In: Tasman W, Jaeger EA, editors. Duane's ophthalmology [CD-ROM]. Philadelphia: Lippincott Williams \& Wilkins; 2007. Chapter 4.

4. Hayden BC, Kelley L, Singh AD. Ophthalmic ultrasonography: Theoretic and practical considerations. In: Singh AD, Hayden BC, Pavlin CJ, editors. Ultrasound clinics. New York: Elsevier ; 2008. p.179-83.

5. Sarikabadayi YU, Aydemir O, Ozen ZT, Aydemir C, Tok L, Oguz SS, et al. Screening for retinopathy of prematurity in a large tertiary neonatal intensive care unit in Turkey: Frequency and risk factors. Ophthalmic Epidemiol. 2011;18(6):269-74.

6. Aydemir O, Sarikabadayi YU, Aydemir C, Tunay ZO, Tok L, Erdeve O, Oguz SS, et al. Adjusted poor weight gain for birth weight and gestational age as a predictor of severe ROP in VLBW infants. Eye (Lond). 2011;25(6):725-9.

7. Gilbert C, Fielder A, Gordillo L, Quinn G, Semiglia R, Visintin P, Zin A, International NO-ROP Group. Characteristics of infants with severe retinopathy of prematurity in countries with low, moderate, and high levels of development: Implications for screening programs. Pediatrics. 2005;115(5):e518-25.

8. McLoone E, O'Keefe M, McLoone S, Lanigan B. Long term functional and structural outcomes of laser therapy for retinopathy of prematurity. Br J Ophthalmol. 2006;90(6):754-9.

9. Cook A, White S, Batterbury M, Clark D. Ocular growth and refractive error development in premature infants with or without retinopathy of prematurity. Invest Ophthalmol Vis Sci. 2008;49(12):5199-207.

10. Bozdag S, Oguz SS, Gokmen T, Tunay Z, Tok L, Uras N, et al. Serum fructosamine and retinopathy of prematurity. Indian J Pediatr. 2011;78(12):1503-9.

11. Ozdemir R, Sarı FN, Tunay ZO, Erdeve O, Canpolat FE, Oguz SS, et al. The association between respiratory tract ureaplasma urealyticum colonization and severe retinopathy of prematurity in preterm infant's $\leq 1250 \mathrm{~g}$. Eye (Lond). 2012;26(7):992-6.

12. Kwitko ML. Surgery of the infant eye. New York: Appleton-Century-Crofts; 1979.

13. Al-Umran KU, Pandolfi MF. Corneal diameter in premature infants. Br J Ophthalmol. 1992;76(5):292-3.

14. Portellinha W, Belfort R. Central and peripheral corneal thickness in newborns. Acta Ophthalmol (Copenh). 1991:69(2):247-50

15. Kirwan C, O'Keefe M, Fitzsimon S. Central corneal thickness and corneal diameter in premature infants. Acta Ophthalmol Scand. 2005:83(6):751-3.

16. Saw SM, Tong L, Chia KS, Koh D, Lee YS, Katz J, et al. The relation between birth size and the results of refractive error and biometry measurements in children. $\mathrm{Br} J$ Ophthalmol. 2004;88(4):538-42.

17. Laws DE, Haslett R, Ashby D, O'Brien C, Clark D. Axial length biometry in infants with retinopathy of prematurity. Eye (Lond). 1994;8(4):427-30.

18. Hirano S, Yamamoto, Takayama YH, Sugata Y, Matsuo K. [Ultrasonic observations of eyes of premature babies. VI. Growth curves of ocular axial length and its components]. Acta Soc Ophthalmol Jpn. 1979;83(9):1679-93. Japanese. 